\title{
The Greek-Latin Dispute Over the Communion of Infants*
}

The problem of the infant communion, which in the Catholic-Orthodox confrontation is rather secondary, has not yet been elaborated on. However, it is an interesting example for the history of theology of how the same theological problem can have different contents and functions, depending on the historical context in which it is raised.

\section{Starting Point of the Dispute}

The communion of infants was abandoned during the $13^{\text {th }}$ century in the Western Church. This was the result of a new Eucharistic spirituality initiated by a reaction to the Berengarian doctrine. The guiding principle of this spirituality was to emphasize the truth about concomitance, and its most characteristic feature was an increase in respect for the saints. The cessation of the communion of infants was motivated by the danger of unintentional insult, which lasts as long as the child is not able to distinguish the Eucharist from ordinary bread. The Eastern Church did not experience a similar reaction, which of course increased mutual differences in spirituality and Eucharistic customs.

The oldest text on the infant communion dispute comes from the famous Libellus de erroribus Armenorum, the official author of which is Pope Benedict XII (1334-1342), while the actual authors were the two Latinising Armenian bishops. They counted 117 Armenian heresies, superstitions and abuses. The publication of this magazine by the Pope provoked a lively reaction in the Armenian Church. The pleas were mostly generalised and exaggerated, included in the form of accusations. The answer to these pleas was taken care of by the synod 
in Sish (1342), convened especially for this purpose. The Synod's explanations are factual and respectful of the Holy See, but at the same time there is much regret in them, especially because of accusations that are particularly unjust or absurd. As for the communion of infants, the Armenians were accused not so much of the mere fact as of binding it to a false doctrine of baptism: that they make the importance of this sacrament dependent on both Confirmation and the Eucharist being given. The Synod in Sish, responding to this accusation, confirmed the custom of giving three sacraments to infants at the same time, but rejected the main accusation as an unjustified insinuation ${ }^{1}$.

The Latin accusation - albeit formulated in a less conciliatory spirit - had a basis in reality. In any case, it is a fact that Gregory Dattivensis (deceased 1411), who acted a little later and who significantly reinforced anti-Roman tendencies in the Armenian Church, openly accused Latin people that their deceased children do not receive salvation because after baptism they do not receive communion $^{2}$. In addition, giving all three sacraments of initiation to infants helped to create an awareness that baptism could only be given by priests. In the correspondence between Pope Clement VI and the Catholicoi of Armenians after the synod in Sish, we find, among other things, the question whether the Armenians recognise the validity of baptism given by a non-priest ${ }^{3}$. This question has at least two aspects, practical and theoretical. In practice, baptism and priesthood can be so closely connected that laity do not dare to give this sacrament even to a dying child. Theoretically, although this is not a necessary consequence of this state of affairs, the validity of baptism given by a priest may not be questioned ${ }^{4}$. In the letter of Clement VI of 29 September 1351, there is a reference to a previously issued order of the Pope for the Armenian Church

$1 \quad$ Mansi, vol. 25 col. 1236.

2 C. Galanus, Conciliationis Ecclesiae Armenae cum Romana, vol. 2, Rome 1661, 590.

O. Raynaldus, Annales ecclesiastici, vol. 16, Coloniae Agr. 1691, 314.

4 Such voices appeared e.g. in older Greek theology, and their source were former canonical regulations reserving communion only for priests and bishops. For example, this is decided by the can. 47 of Apostolic Canons. In: luris ecclesiastici Graecorum historia et monumenta (publ. B. Pitra), vol. 1, Rome 1864 23. A similar provision is contained in the Apostolic Constitutions, book 3, chap. 13 n, where a non-priest who dared to baptise was even compared to the sons of Korah. Ibid., 235. Photius only questioned the validity of baptism given by someone who pretends to be a priest, but he considered baptism given by a lay person for someone in mortal danger to be important. Letter to Leon Archbishop of Calabria (PG. vol. 102, col. 774 n.). In the compendium of synodal canons prepared in 1336, M. Blastaris considered every baptism given by a priest to be doubtful and ordered to repeat it. Syntagma alphabeticum (PG, vol. 144 col. 1108). 
to stop giving communion to infants ${ }^{5}$. This would be Rome's first formal intervention in this matter.

The Florentine Council took a different, more tolerant stance in the dispute over the communion of infants. The formula of the union proposed by the Latin side included the demand to renounce heresy and total tolerance for other differences. As a result of the discussion, the Greeks adopted the position of the Romans on three traditionally controversial issues: the truth about the origin of the Holy Spirit a Patre Filioque, the primacy of the Pope, and the doctrine of Purgatory. The Romans, on the other hand, treated the union not as a return of those who had gone astray, but as a reconciliation of opposing brothers, the sons of one mother Church ${ }^{6}$.

However, it is not known whether Florence dealt with differences considered to be non-heretical. The preserved files of the Council are silent on this subject; however, some data indicate that this issue was the subject of the Council's discussions. Mansi, for example, signals the opinion expressed by St. Antoninus, a member of the Council, although not yet as a Florentine bishop. Among the eastern rites, which do not contain heresy, although they differ from the rites of the western church, Antoninus also mentions the communion of infants ${ }^{7}$.

His statement shows a relationship with the Apostolic Constitution of Accepimus nuper of Leon X of 18 May 1521, which contains the same list of Greek separations ${ }^{8}$. In this document, the Pope strongly defends the Eastern rite in connection with the Latin bishops of the Ionian Sea islands. Leon X states that the criticism of the Greeks on account of their distinctiveness is incompatible with the findings of the Florence Council. This would argue in favour of the existence of a conciliar document, which is unknown today in this case: probably from there both Antoninus and Leon X drew up a list of approved Greek separations. Contrary to St. Antoninus, the Constitution does not make the slightest allusion about the alleged superiority of Latin over Greek rites. Its general tone indicates that the Pope recognises the equivalence of Greek rites rather than just tolerating them.

The classical positions of eastern theology were first defined by St. Simeon of Thessaloniki and the Nilus of Rhodes. Simeon (deceased 1429) represents the intransigent direction. His Dialogue in Christo adversus omnes haereses is an

O. Raynaldus, op. cit., 315.

Union bullae of 6 July 1439, in: Documenta Concilii Florentini de unione Orientalium (publ. G. Hofmann), vol. 1, Rome 1935 h. 16 n.

Mansi, vol. 31, col. 1812.

8 Monumenta Ucrainae Historica, vol. 13, Rome 197383 n. (in short: MUH). 
extensive argument against the Latins. It culminates in a several-century process initiated by the Constantinople synod of 692 (called in Trullo), the formation of classical anti-Latin polemics of the Greeks. The arguments used there still constitute an iron repertoire of Orthodox polemics with Catholicism. In removing infants from communion, Simeon sees above all the risk of their loss of salvation? In his work De sacramentis, he made this allegation particularly harshly clear ${ }^{10}$.

Nilus, Metropolitan of Rhodes, living one generation before Simeon, spoke more gently on the same subject. Referring to can. 84 of the Synod in Trullo, which refers to the communion of infants, he points out that no canon hinders children's access to the holy table. Nilus of Rhodes, however, does not go so far as to claim that by refusing it to children eternal salvation was closed to them in this way ${ }^{11}$.

Comparing the positions of Western and Eastern theology in the dispute over the communion of infants, it should be noted that both sides are fundamentally intolerant to the custom of the other side, with the western side showing a slightly higher degree of tolerance. The allegation of misrepresentation in western arguments appears at most indirectly and the Florentine formula, although open also to diminishing interpretations, even proclaims the fundamental equivalence of the two customs. For both parties, the basic principle of the dispute is presented in a different way, to which individual arguments are subordinate. Namely, the East defends the communion of infants in the name of fidelity to tradition, while the West defends its custom in the name of respect for sacred mysteries. In this situation, Western theology can at most proclaim the superiority of its own custom but it cannot accuse heresy of the traditional custom against it. The situation of eastern theology is more difficult in this respect because there are no equally important contraindications to accuse the opposing side of heresy, so this accusation appears more easily and more often in it.

\section{The Union of Brest Period}

After the fall of Constantinople, the main area where western Christianity met or tried to meet the eastern was the Russian lands. During the $16^{\text {th }}$ century, the first descriptions appeared of customs of the Moscow state, which was extremely

9 PG, vol. 155 col. 102.

$10 \quad$ Ibid., col. 236.

11 Responsio decima ad Ionam Hieromonachum, in: Inedita canonical responsa Constantinopolitani Patriarchae Lucae Chrysovergae et Nili Metropolitae Rodensis, Odessae 190362 (quote for M. Jugie, Theologia dogmatica Christianorum Orientalium, vol. 3, Paris 1930, 302). 
exotic for Europe at that time. However, there is a lot of disinformation in these brochures. J. Fabri, the confessor of the Roman king Ferdinand, writes in 1521 that the Moskal's Confirmation is given only by bishops, and is received only after reaching adulthood ${ }^{12}$. On the other hand, he knows nothing about communion immediately after baptism. He only remembers with dismay that the Eucharist is given there to three year old children ${ }^{13}$. Another informant at the time, A. Guagnini, attributes to the local Church total conformity with Latin practice in this respect ${ }^{14}$.

First of all, however, the meeting of both Christian traditions took place in the Kingdom of Poland at that time. The first Polish work devoted to the Ruthenian religion, by the Kraków professor Jan of Oświęcim (Sacranus), was created on the wave of regret over the failure of the union, and is therefore unfriendly to Ruthenians and their religion. The number of three eastern errors in Lyon and Florence grew to 47. The Sacranus also enumerates 22 consecutive schisms that the Eastern Church had undertaken over the centuries. However, he either does not know or does not consider it a mistake to give communion to infants ${ }^{15}$.

The intellectual situation in Ruthenia and the pressure of Protestantism in the country were not conducive to interest in the issues of Eastern Christianity. This state of affairs changed only when the idea and then the implementation of the union with the Ruthenians encouraged many to grab the pen, both supporters and opponents ${ }^{16}$. It is interesting to look at the tracks of the discussion about the communion of infants at the time, as it reflects well the mutual relationship between the two faiths, which was finally perpetuated at that time and is still valid to this day. In particular, it is worth looking at the mechanism that has made the list of heresies that the Orthodox Church exposes to Catholicism much longer than the Catholic list of Orthodox heresies. The main ideologue of the Union was Fr. P. Skarga. His doctrinal settlement, published in 1577,

12 J. Fabri, Religio Moscovitarum, in: [J. Łasicki], De Russorum, Moscovitarum et Tartarorum religione, Spirae 1582177.

13 Ibid., 183.

14 A. Guagnini, De religione Moscovitarum omniumque Ruthenorum. In: [J. Łasicki], op. cit., 268.

15 Sacranus, Elucidarius errorum ritus Ruthenici. Cracoviae 1500. In: [J. Łasicki], op. cit., 184-219.

16 Cf. two bibliographical studies: M. Wiszniewski, Historia literatury polskiej (History of polish literature), vol. 8, Kraków 1851 248-496; A. Brückner, Spory o unję w dawnej literaturze (Disputes over the union in old literature), KH 10 (1896), no. 3, 578-644. 
follows the line of the Florentine Council ${ }^{17}$. Although Skarga shifts the focus to the problem of the primacy of the Pope, the basic Florentine assumptions did not changed: to recognise the doctrinal purity of the Roman Church, while to reduce the demands on the Eastern Church to truly relevant. To this end, the author distinguishes between liturgical and dogmatic distinctions, the latter being the only ones that are important to him ${ }^{18}$. In spite of these assumptions, the number of eastern heresies in Skarga increased to 19, of which - a characteristic feature - as many as 7 relate to Eucharistic errors ${ }^{19}$. Infant communion was not included in the list because the Council of Trent clearly stated that there was no doctrinal error in this custom.

In the first years after the signing of the Union in Brest in 1596, its supporters not only stressed the equivalence of the two traditions and the invalidity of liturgical differences, but also preferred to use a more conciliatory Florentine list than the one drawn up by the Complaint, as regards dogmatic differences. If they sometimes mentioned the communion of infants, it is only when calculating the differences that deserve to be respected ${ }^{20}$.

With time, however, reference was made to this rite for polemic purposes. Namely, the anti-Uniates, initially poorly prepared theologically to polemics with Catholicism, drew on the anti-Catholic achievements of Protestants and emphasised, among other things, the accusation that Catholics give communion only in one form. Although this allegation did not directly concern individuals, by reason of the union they felt obliged to defend the dogmatic legitimacy of the Latin custom. The fact that communion of infants is usually given to infants in the Eastern rite in one form, and yet such communion is not considered unworthy or less worthwhile, proved to be a useful argument. Bishop H. Pociej, in his great apologetic letter to Patriarch Alexandria Meletius (1601), quotes this argument twice ${ }^{21}$.

M. Smotrycki also refers to the communion of infants as an argument in a letter from 30 October 1629 to the Patriarch of Constantinople, Cyril

17 P. Skarga, O jedności Kościoła Bożego pod jednym Pasterzem, y o greckim od tey jedności odstapieniu, Vilnius 1577. Quote for: Pamiatniki polemiczeskoj literatury (Russkaja istoriczeskaja bibliotieka), vol. 2, Petersburg 1882 (a text with annotations of the additions made to the edition: Kraków 1590).

$18 \quad$ Ibid., col. 492.

19 Ibid., col. 471-477.

20 Cf. e.g: Harmonia albo Concordantia wiary, sakramentów y ceremoniey Cerkwi ś. orientalnej z Kościołem ś. rzymskim, 1608. In: Pamiatniki polemiczeskoj literatury, op. cit., vol. 2 col. $193 \mathrm{n}$.

${ }^{21}$ H. Pociej, Obrońca Wiary S. Katolickiey, Supraśl 1768, 62.101. 
Lukaris $^{22}$. Smotrycki, one of the leading anti-Uniate publicists and the creator of an excellent grammar of Russian, in July 1627 secretly professed the Catholic faith before the Uniate Metropolitan Józef Rutski ${ }^{23}$ Two years later he writes a letter to Lukaris in which he asks the Patriarch to make efforts to unite the two Churches. Perhaps it was an attempt to implement the union's plans of Prince Konstanty Ostrogski, who was outraged by the only partial union carried out by Bishops Pociej and Terlecki. According to Smotrycki, a new point of disagreement was added to the old discrepancies between the two Churches, namely the matter of communion in one form. However, this problem should have not constituted a significant obstacle because also in the Eastern Church infants were given only the Lord's Blood, while the sick were given only the Body itself, and it is not for them to criticise in the Romans what they do on their own ${ }^{24}$.

While the Catholic side not only did not accuse the anti-Uniates of heresy because of giving communion to infants but even positively used this fact in their polemics, the opposite side quite quickly accused a violation of faith due to the abandonment of this rite in the Catholic Church. For the first time, this accusation was formulated in the anonymous work Antigraphe ${ }^{25}$. This brochure was a response to two Uniate letters: the Script, which is unknown today, and the Harmony mentioned above. The author reminds us that originally the Roman Church also observed this rite, and the witness is called by Fr. P. Skarga himself, who mentions this custom in the biography of St. Cunigunde ${ }^{26}$. At the same time, the accusation of abandoning the communion of infants illustrates the more general accusation that it is the essence of the Roman Church to honour the spirit of novelty ${ }^{27}$.

On the Catholic side, the first attack on the communion of infants took place as early as in 1642 . He was accompanied by K. Sakowicz, the leading polemicist of the anti-Uniates next to Smotrycki, later by a Uniate (from 1625) and an archimandrite in Dubin. Sakowicz breaks with the previous Catholic tactics of not exaggerating dogmatic differences, while the custom of those defending

22 MUH, vol. 2, 98-109.

23 Ibid., 31.

24 Ibid., 103.

25 Antigraphe albo odpowiedź na Script uszczypliwy przeciwko ludziom starożytnej Religiey Greckiey od Apostołów Cerkwie Wschodniey wydany, Vilnius 1608. Cf. B. Waczyński, Czy Antigrafe jest dziełem Maksyma (Melecjusza) Smotryckiego? (Is Antigrafe the work of Maxim (Meletius) Smotrycki?), RTK 1 (1949), 183-210.

26 Cf. P. Skarga, Żywoty świętych Pańskim, vol. 5, Warsaw 1880, 72.

27 Antigraphe, op. cit., c. 38. 
themselves against the Orthodox Union lengthens the list of the opponent's mistakes to the maximum. The very title of the book reveals the author's basic idea $^{28}$. The book opens with a register of these anti-Uniate heresies. In the chapter dedicated to the Eucharist, we find the accusation that "giving communion to infants for no reason brings great dishonour to the Blessed Sacrament"29. This accusation is still further developed in the book. The basis for the deductions is classical Catholic teaching on this subject, but commented on subjectively. For example, from the decisions of the Council of Trent, the author only recalls that the doctrine of the necessity of the communion of infants has been rejected, but does not notice that stigmatisation of the rite itself - as it does - is contrary to the teachings of the Council. It is also significant that Sakowicz himself, while working in Dubin, abolished the communion of infants, although he met with some resistance ${ }^{30}$. He did it many years before the Zamość Synod of 1720, which finally put an end to this custom.

It seems that nobody from the Catholic side tried to bring Sakowicz to order ${ }^{31}$. Against him, however, was Pimin from the Kiev Academy, under the alias of which the Metropolitan Mohyla hid himself. With regard to the accusation of the communion of infants, the defence was no less violent than the attack, but more logical. The author is based on the argument about the necessity of communion for salvation, although he does not draw such extreme conclusions as Simeon of Thessaloniki in his times. He refers to the Fathers of the Church, mainly Western Fathers, of course. Everything is subordinated to the accusation that it is in the nature of the Roman Church to deviate from the truth and to run for novelties ${ }^{32}$.

28 K. Sakowicz, Epanorthosis abo perspektiwa y obiaśnienie błędów, herezyjej y zabobonow w greckoruskiej cerkwi dizunitskiej, Kraków 1642.

29 Ibid., c. C4 retro.

30 Ibid., 24.

31 Sakowicz's aggressive attitude met with far-reaching approval of the Latin Bishop of Lutsk, A. Gembicki. He agreed to produce a translation of the resolutions of the Kiev Synod of 1640, prepared by the archimandrite, with harsh remarks on the margins. Cf. Sobór Kijowski schizmaticki przez oyca Piotra Mohiłę złożony i odprawiony roku 1640, w którym iż wielkie absurday przeciwności wierze świętey katholickiey znayduja się, przeto czułością pasterską i staraniem Andrzeia Gembickiego, biskupa Łuckiego, na przestrogę Rusi nie w uniey będacey, żeby wiedziała jakiego pasterza naśladuje: który jeśli sam nie wie jako wierzy, a jakoż ich może prawdziwej wiary nauczać?, Warsaw 1641, Kraków 1642.

32 E. Pimin, Lithos abo kamień z procy prawdy cerkwie świętey prawosławney ruskiey na skruszenie fałeczno ciemney Perspektiwy albo raczey Paszkwilu od K. Sakowicza, Ławra Pieczarska Kijowska 1641, 70ff. 
In the period of the Brest Union it is possible to observe a typical pattern of behaviour towards unification proposals. Since this controversy is dogmatically secondary, parties seeking reconciliation - all Latin theologians and Uniate theologians - try to emphasise the doctrinal legitimacy of the existing differences. Anti-Uniate theologians, on the other hand, are interested in emphasising the dogmatic importance of even secondary differences, in order to protect their Church from the destructive influence of the union in their opinion.

Sakowicz's speech was an announcement of a change in this situation. Namely, it expresses its resignation from the hope of unification of the entire Eastern Church in the Kingdom of Poland for the union. As this hope became increasingly more faint, the Uniate Church was somehow forced to look for its own formula of identity and to define its attitude towards the anti-Uniate Church. Sakowicz was the first to understand the situation intuitively, although probably not very consciously. In 1633 Władysław IV recognised the legality of the anti-Uniate hierarchy in his country. It was becoming increasingly clear that the anti-Uniates would remain a permanent and significant phenomenon in the country and that the Union process encountered almost insurmountable barriers and would stop there. As a result, in the Uniate Church there was a need for a clear separation from the anti-Uniates and development on one's own territory. In this way, the list of heresies exhibited by the Uniates on the Orthodox Church also became much longer; as part of this trend, infant communion became one of the first elements that the Uniate liturgy tried to change.

\section{Disappearance of Infant Communion in the Uniate Church}

Both in Florence and in Brest the equality of both practices with regard to the communion of infants was recognised. So how did it happen that in a relatively short time the superiority of Western discipline was recognised? A partial answer to this question can be found in the treaties on this subject of P. Arkudiusz and $\mathrm{K}$. Galano, two outstanding Uniate theologians of the $17^{\text {th }}$ century ${ }^{33}$. Both theologians were closely connected with the Union movement within the territory of the Kingdom of Poland. The Greek Archduke personally participated in the Brest Synod in 1596, the Italian Galano in 1664-1666 stayed in Lviv with the union's mission among the Armenians.

33 P. Arcudius, De concordia Ecclesiae occidentalis et Orientalin in septem sacramentorum administratione, Paris 1626; C. Galano, De communione puerorum ante perfectum usum rationis, in: Conciliationis Ecclesiae Armenae cum Romana, vol. 2, Rome 1661, 589-603. 
According to the Archdiocese, the doctrine of the salvific necessity of giving communion infants is proclaimed not by the Greek Church, but by Greek heretics. Heresy is based on two erroneous assumptions: 1) Baptism is invalid if it is not affirmed by Confirmation and Communion; 2) Baptism forgives only sins, while God's life is given by Confirmation and Communion. Meanwhile, "through baptism man truly and inwardly becomes a righteous and holy son of God, and thus an heir and participant of the heavenly kingdom." Baptism would not be a sacrament of rebirth if we did not receive life through it. Children who die without baptism do not suffer, they only do not receive salvation. On the other hand, the Eucharist is not necessary for salvation necessitate medii, nor is it necessary for infants to help repel temptations, nor is it necessary for babies to eat it spiritually in voto Ecclesia. Hence the danger of insult during distribution is a sufficient reason not to give communion to infants. The postulate of Arcudius is therefore unequivocal: although the Roman Church does not condemn the Greek rite, the Greeks would have done better if they had adapted to the Roman Church rather than abiding by the old custom ${ }^{34}$.

The theology of Arcudius, although of a large class, is undoubtedly a western theology. This is indicated not only by its scholastic terminology (necessity of necessitate medii, sacrament in voto Ecclesiae), but above all by the one-sided concept of the salvific role of the Eucharist. It derives from the Augustinian theology of grace, understood mainly as a help on the way to salvation. Although the Eucharist for Arcudius is the sacrament of belonging to the Body of Christ, on this level the actual reception of the Eucharist is not necessary even for adults, but it is necessary as an aid in the fight against sin.

In the same spirit and using similar arguments he develops Galano's arguments. A new element of this theologian's work was the clear definition of the main objection against Western custom, formulated in the spirit of Western theology. Even if communion is not necessary for infants, it undoubtedly increases the grace of baptism. So why is it denied to infants? In answering this question, Galano does not go beyond the traditional arguments of Western theology, namely, he refers to 1 Corinthians 11:28 for the conscious reception of the Eucharist, while infants are not capable of receiving this sacrament with faith and devotion. The practical proposal for a treaty is also the same as in the case of Arcudius. The author advises Armenians to adapt to the Roman custom as a better expression of respect for the Eucharist ${ }^{35}$.

34 P. Arcudius, op. cit., 36-45.278-319.

35 Cf. Galano, op. cit., $596 f$. 
Both treatises are enlivened by the same concern for demonstrating the validity of Western practice and the same lack of interest in the arguments in favour of preserving traditional customs. In both treatises, it is based on Western theology, while theoretical arguments are placed above the existing tradition. In a word, Uniate theology, cutting itself off from the polemical, anti-Western tradition initiated by Simeon of Thessaloniki did not develop its own position, more in line with the spirit of the East, on the communion of infants and adopted the solutions of Western theology in their entirety. The practice quickly adapted to theology.

In the Russian Church the communion of infants was abolished by the Zamość synod in 1720. The clause authorising priests not to make changes if this threatens to be scandalous shows that the custom that was then in common use, or at least not dying out, was abolished. The text speaks with great respect about the custom to date, while the change is justified in terms of due reverence for the Blessed Sacrament and the religious harmlessness of depriving infants of communion. The Synod also decided - following the Western custom to catechise children who are to receive Holy Communion after reaching an appropriate age ${ }^{36}$.

The Zamość Synod is undoubtedly a landmark date in the history of the Greek Catholic Church in the Kingdom of Poland. Depending on the point of view, it is said to have been a summary of more than a hundred years of united Catholicism or more than a hundred years of their Latinisation. The most important subject of the reform was the revision of liturgical books, as a result of which the Uniate liturgy was finally harmonised with the Catholic theology of the time.

The process of the disappearance of infant communion in other Uniate Churches is also significant. In this intervention of 1521 Leon X defended, among other things, the legitimacy of the communion of infants. In 1564 Pius IV included the communion of infants among the heretical and godless practices and ridiculous madness committed by the Italo-Greeks ${ }^{37}$. This is the first papal statement against this rite after the Florentine Council. The sharp tone of the speech was caused by the schismatic tendencies of the Italian Greeks at the time, which led the Pope limiting their previous exemption. The Pope's inclusion of infants on the list of Greek errors is astonishing, all the more so as

36 Synodus provincialis Ruthenorum habita in civitate Zamosciae anno 1720, Rome 1724. Quote from the second edition: Vilnae 1777, 66f.71f.

37 Pius IV, Bullarum, diplomatum et privilegiorum sanctorum Romanorum Potificum, vol. 7 , Augustae Taurinorum 1862, 271f. 
the Council of Trent, convened by the Pope two years earlier, clearly stated the orthodoxy of this ancient custom. It may be added that the Pope's decree does not contain a formal ban. The list of errors written in anger reveals the author's personal aversion to the Italian Greeks.

The communion of infants in the Italian Uniate Church was not abolished until Benedict XIV with the Constitution of Etsi pastoralis of $1742^{38}$. Although the Popes sometimes suggested to the Eastern Churches to adopt the Roman custom, they refrained from direct interventions ${ }^{39}$. Benedict XIV himself was an outstanding and kind expert in Eastern rites. He also repeatedly ordered Latin Ordinarians and priests to respect eastern liturgical differences. However, the secret of his speech on infant communion seems simple. Namely, Rome applied different rules to the Uniate Churches in the East, while treating Uniates scattered among Latins differently. In the latter case, he was rather interested in the slow absorption of the Uniates by the Latin Church, without even hesitating to use certain forms of discrimination for this purpose ${ }^{40}$. In particular, he supported the reform of those rituals that somehow influenced the doctrine.

The correctness of the above interpretation is indicated by the fact that in the famous encyclical on Eastern rites Allatae sunt of 1755, the same Benedict XIV suggests abandoning the communion of infants, but does not issue any order on this subject ${ }^{41}$. Although the papal wish is different from the injunction, it is undoubtedly a form of pressure. The fact that the Pope wishes to stop the communion of infants in this encyclical sheds new light on the problem of Latinisation because the encyclical is directed against the Latinisation of Eastern rites. Benedict XIV saw the abandonment of the communion of infants not as a sign of Latinisation, but only as "a consequence of the Catholic principle of special reverence for the Blessed Sacrament."

This gives rise to a difficult and sensitive problem, where the boundary between Catholicisation and the Latinisation of the Eastern rites runs. Catholicisation expresses the Holy See's concern for the doctrinal legitimacy of Eastern Christianity. On the other hand, Latinisation, which means Latin influences that have no dogmatic or pastoral justification, is intrinsically undesirable because it contributes to the disappearance of the rich tradition of the Eastern rite.

38 Benedictus XIV, Bullarium ab anno 1746 (!) usque ad totum annum 1748, Rome 1761, 76.

39 Cf. Letter by Gregory X of March 1577 to the Patriarch of the Maronites, in: Bullarium Maronitarum (ed. T. Anaissi), Rome 1911, 72.

40 Cf. the rules on mixed marriages in the aforementioned Constitution of Benedict XIV, op. cit., 80 .

41 Benedictus XIV, Opera omnia, vol. 8, Prati 1843, 331f. 
In practice, it is sometimes difficult to draw a line between the two phenomena, especially - as can be seen in this case - when there are many reasons for both a change and abandonment of a change.

In the history of the Eastern Churches, all too often, under the slogan of eliminating doctrinal errors, this boundary has been moved in favour of Latinisation. On the other hand, the Catholic opponents of Latinisation generally did not face this problem: by postulating de-Latinisation, they kept quiet about the changes in their rite that were too clearly related to dogma.

A characteristic feature is the coincidence of some dates. In 1596, the Holy See undertook to fully respect the request of the Brest Synod that all rites and ancient ceremonies of the Greek Churches contained in the traditional liturgical books be left unchanged and completely intact ${ }^{42}$. In the same year, the synod of the Maronite Church, the oldest Uniate Church, introduced significant liturgical changes ${ }^{43}$. Similarly, Pope Benedict XIV, who forbade Italian Uniates to give communion to infants, and advised all Uniates to stop this ritual, issued different instructions to Coptic missionaries. This was the response of the Congregation of the Holy Office of June 14, 1741 to the letter of the missionary Remigio da Trento. This missionary describes in detail the insults to which the Blessed Sacrament is threatened when given to infants. Undoubtedly he was not personally convinced of this ritual and expected that the Holy See would authorise missionaries in Egypt to stop it. However, the Congregation's answer was completely different: although it is better and more appropriate not to give communion to infants, this custom should not be pushed forward as contrary to the Copts' rite, which is ancient and does not oppose faith. In order not to discourage the very idea of union, missionaries should respect all rituals that do not endanger the soul and do not oppose the dignity of the Church. With regard to the communion of infants, it is sufficient to exercise due care to ensure that the sacrament has the respect it deserves ${ }^{44}$.

It would be unfair to accuse the Holy See of having a double policy towards the Eastern Churches. It is enough to recall that in all Uniate settlements Rome demanded a clear renunciation of views that it considered heretical. However, it showed considerable tolerance for those rituals which it considered inappropriate (e.g. some of the seven Eucharistic errors listed by P. Skarga) or less appropriate

42 MUH, vol. 1, 169.

43 The records of the Maronite Synod on Mount Lebanon from 1596 were published by Mansi, vol. 35, col. 1021-1028. The Synod prohibits, among other things, communion to infants (can. 7). This ban will be recalled by the synod on Mount Lebanon in 1736, Ibid., vol. 38, col. 47.

44 Collectanea S. Congr. de Propaganda Fide, vol. 1, Rome 1907, $100 \mathrm{f}$. 
(e.g. the communion of infants). In these matters, Rome basically chose a strategy of patience and not imposing anything by force. Changes were made only when the Uniates themselves became mature in their understanding and need, although sometimes the Holy See supported and even accelerated the process. Only in the case of the Italian Greeks was there direct papal intervention, while in all other cases the change was passed by the synods ${ }^{45}$. However, judging only the method of change can be accused of the intention to deprive the Uniate Churches of their eastern identity at the root of the Roman idea of the EU.

This accusation should also be considered using the example of the Zamość Synod, especially criticised by opponents of the Union ${ }^{46}$. To some extent, it was also undermined by the Uniate opponents of Latinisation ${ }^{47}$ Resolutions of the synod only give general guidelines, rarely entering into specific matters. In the executive regulations to the liturgical reform undertaken by the synod, the justification of individual decisions was abandoned ${ }^{48}$. That is why it is necessary to refer to a detailed study of the archimandrite of Polikarp Filipowicz, who, as a censor, prepared implementing regulations ${ }^{49}$.

The liturgical reforms can be divided into four groups. The first included dogmatic reforms aimed at adapting the liturgy more closely to the new dogmatic situation that arose since the Union. The recollections of the Pope in the liturgy had been consistently introduced, and the symbol of faith had been placed in Filioque. Texts that might suggest that the fate of the deceased has not yet been resolved by the time of the final court had been retouched. The references to only seven general councils were removed, as well as references to the idea of communion with the anti-Uniate Church, e.g. the reference to customs or Kyiv synods. In the same way, the recollections of St. Grzegorz Pałama and Marek Efeski were removed. Finally, a series of reforms were undertaken, the guiding principle of which was to show special respect for the Eucharist: it was forbidden to bring wine already mixed with water to church, the ritual of pouring

45 To these Uniate synods, which abolished the communion of infants, two Melchick synods from 1790 and 1806 should be added. Mansi, vol. 46, col. 633.732.

${ }^{46}$ Cf. J. Siemaszko, Zapiski, vol. 1, Sankt-Peterburg 1883; G. Chruszczewicz, Istorija Zamojskago Sobora, Vilnius 1880.

47 Cf. M.M. Solowij, De reformatione liturgica Heraclii Lisowvskij, Archiepiscopi Polocensis, Rome 1950 h. 120-125.

48 Ob isprawlenii bogosłużebnych knig. Okrużnoje pismo uniatskago mitropolita Afanasija Szeptyckago k duchowieństwu ot 1738 goda, Poczajew 1905 (ordinance on the communion of infants can be found on page 30). This text, published as part of the anti-Uniate action, is supplied with a biased discussion of synodal regulations.

49 MUH, vol. 5 h. 371-415. 
warm water into the cup was abolished, scrupulousness was increased by the Eucharistic crumbs and the communion of infants was abandoned. Finally, in defence of the virginity of St. Joseph, the claim that he was a widower was removed, and the verse that the prophet Elijah had been sanctified even before his conception was modified.

The second group consisted of reforms with a pastoral goal. Long prayers of almost half an hour during the sacrament of penance, which made it practically impossible to use the sacrament more often and more widely, were replaced by a short liturgy, Latinised to such an extent that it even added absolution from ecclesiastical censorship. The ban on baptism during Lent was lifted and the canon refusing to baptise the deceased as a result of the duel, even if they had repented before their death, has been relaxed.

The third group included reforms directed against anti-Latin texts or texts that could be interpreted as anti-Latin texts. For example, the phrases directed against Latin people that they use unleavened bread have been deleted, the remark that baptism by only one immersion is heretical and that in such a case the baptism should be repeated and the mention of the alleged heresy of Pope Honorius had been erased.

Finally, the fourth group introduced a series of detailed deletions and retouches to adapt the liturgical books to the current liturgical reality or to adapt them to the new mentality. For example, orders no longer observed that marriage should be celebrated that baptism should be preceded by forty days of strict fasting, and participation in the liturgy by three days of sexual restraint, which also applies to lay people, had been removed. An intervention was made in a text expressing the assumption that God's judgement will take place in March. In the description of Our Lady of Sorrows, the emphasis was shifted from the external manifestations of pain to the plane of the spirit. The form of "Save me by faith and hope alone," which could be used by Protestants, was replaced by the prayer "Save me by infinite goodness and thy mercy."

The Zamość Synod became the basic point of reference for the Orthodox Church, especially the Russian criticism of the Union. In addition, this synod has been constantly invoked to justify the use of violence against the Uniate Church in 1839 and 1874. Indeed, Western influence on both the resolutions of this synod and the development of the Uniate Church in general was undoubtedly something. On the other hand, it is doubtful whether the changes introduced by virtue of their very source deprived the Eastern Church of its identity or obscure it. This allegation could relate at most to some of them. For it does not seem that the essence of Eastern spirituality is total impenetrability when it comes to external influences. Nor can it be argued that this spirituality 
by its very nature rejects development or the need for reform, or that it must be anti-Western or indifferent to changing pastoral needs.

The polemic about the Latinisation of the Eastern Church resembles a discussion between Slavophiles and settlers (ophthalmologists) about Russia's attitude towards the West. Just as one cannot believe that Kirejewski or Axakov were better Russians than Bieliński or Hercen, or vice versa, it would be just as risky to claim that the Uniate Church is less eastern than the Orthodox Church. Besides, the Orthodox Church is also not alien to flying tendencies, as evidenced by the role of Thomism in the Kiev Academy or the Protestant traditions of Russian school theology in the nineteenth century. As far as the Zamość Synod is concerned, it undoubtedly reflects the occidental tendencies of the living Church, whose shepherds honestly cared for the spiritual goodness of the sheepfold entrusted to them, and at the same time were sincerely attached to their rite.

Finally, it is worth summarising the reasons for the disappearance of infant communion in the Uniate Church. Although giving communion to infants does not violate any dogma, Catholic theology has pointed to dogmatic reasons, recommending that this custom be abandoned rather than upheld. The main reason for this was special respect due to the Eucharist, while the secondary reason was the fact that young children were unable to distinguish the Eucharist from ordinary bread. Therefore, the Holy See generally supported the process of departing from the ancient custom, also when it was strongly committed to defending the Eastern rite from unnecessary Latin influences. In principle, however, the changes came from the Uniate Churches themselves, although Uniate theology did not develop its own perspective on the subject, repeating only Western approaches. This state of affairs was largely due to the fact that Eastern traditional theology treated this problem in a polemical, anti-Western spirit. Moreover, the abandonment of the communion of infants brought some pastoral fruit in the form of the obligation to catechise before the first communion.

On the other hand, the dogmatic fuzziness of the problem allowed different positions to be taken on it, depending on the circumstances. As a rule, during the formation of the union, the Holy See maintained respect for the communion of infants, as well as for all rites that did not directly oppose Catholic dogma. The changes came usually after many years of communion with Rome and were a sign of the final acquisition of Catholic consciousness by the Uniate Churches, as well as an expression of a loss of hope for the Orthodox Church's union adjacent to a given Church. Different solutions to this problem reflect the classic tension between centripetal and centrifugal tendencies in the Uniate Church of the Christian East. There is no reason to attribute any of these tendencies to a monopoly on authentic Eastern spirituality. 


\section{The Problem of Infant Communion in Accusations of Latinisation of the Union}

The murders committed in 1705 by Tsar Peter on the Basilians in Polotsk heralded a new period in the history of the Russian Uniate Church ${ }^{50}$. Taking advantage of the weakening and then collapse of the Kingdom of Poland, the Tsardom began a decisive policy of violence against the union without any ideological argument or polemics. As we know, there was no shortage of rape - mutual rape - during the enlargement of the Union. However, while in connection with the Brest Union a rich theology developed, both propagating and fighting the union, now the polemic theology had been replaced by imperial demonstrations and official writings of Orthodox bishops and tsarist governors. In the times of the Kingdom of Poland, decisions about the union were made by the interested parties themselves. For example, the diocese of Przemyśl adopted the union only in 1692, the Lviv diocese in 1700, and Łuck in 1702, because the bishops of these dioceses did not join the union until then. The anti-Uniate hierarchy was allowed to exist even in those cities whose rightful bishops accepted the union, which was tantamount to allowing for the existence of a diocese in the Uniate diocese. Now the Tsardom had appropriated the right to decide on the faith of the subjects. Its policy consistently sought the complete liquidation of the union and in a short period of time it reached its goal, despite the interruption in persecution that took place during the reign of Paul I and Alexander I.

In view of the complete lack of polemic literature during this period, the study of the problem of infant communion must necessarily confine itself to describing the mechanism of this silence, as well as the restoration of the paths of liturgical reform, carried out under the slogan of returning to the pure Eastern liturgy. The period of persecution during the reign of Catherine II may be omitted, despite all its sharpness, as there was no attempt to interfere in the liturgy celebrated by the Uniate Church at that time ${ }^{51}$.

The official beginning of the liquidation of the union was - inspired by the memorial of a young Uniate priest J. Siemaszko - the depiction of Nicholas

$50 \quad$ Ibid., 14-28.

51 Cf. extensive set of documents, MUH. vol. 7. The military action of Catherine was accompanied by propaganda developed by G. Konisski, the Orthodox archbishop of Mohilev, about the alleged persecution that the Orthodox Church was supposed to suffer at that time from the Uniates. G. Konisskij, Słowa i rieczi, Mogilew 1392. The history of the whole action was prepared in the biased spirit by M. Kojałowicz, Istorija wozsojedinienija zapadno-russkich uniatow starych wremien, Saint-Petersburg 1873. 
I from 22 April 1828, establishing a church college of the Greek-Uniate Church ${ }^{52}$. The tsar imposed on the college, among other things, the obligation to ensure that the liturgy in the Uniate Church was purely eastern, not polluted by foreign influences, which was guaranteed in the Uniate bullae of 1595 . The show was unequivocally directed against the Zamość synod ${ }^{53}$. The more far-sighted immediately saw in it a stage on the road to the liquidation of the union ${ }^{54}$. In a short period of time new tsarist and college decrees appeared, which introduced the Russian language into schools and seminars, abolished Basilian monasteries, ordered the expulsion of organs, bells, limited contacts with the Latin Church and the suchlike. The new regulations were published by the Tsarist authorities $^{55}$. At the same time, the repression of priests opposed to the changes took place, such as expulsion from the parish, flogging, imprisonment, penance in an Orthodox monastery or deportation.

The key factor was the decree of the college of 7 February 1834, which ordered the Uniate Orthodox churches to accept liturgical books, printed in the synodal printing house in Moscow $^{56}$. In a memorial to the government from 3 October 1837, Siemaszko himself stressed that the Uniate religion consists almost exclusively of simple people, for whom external differences are the most important obstacle to turning to Orthodoxy. This explains why it was necessary to introduce the decoration and liturgical rituals of the Greek-Russian Orthodox Church into the Uniate Church. With all their practical significance, they did not violate dogmatic and fundamental beliefs, and therefore, according to the author, they could not give either the Uniate clergy or the Latin an important reason for protest or justified complaints ${ }^{57}$. The "Uniate Work" - as Siemaszko perversely calls the whole action - was clearly subordinated to Great Belarusian nationalism, with the aim of transforming the Uniate "from semi-Polish Catholics into Orthodox Russians." ${ }^{\text {"T }}$ This transformation was to take place "imperceptibly" (nieczuwstwitielno, niezamietno - words often appearing on the pages of Siemaszko's Notes).

52 MUH, vol. 8, 146-150.

53 This was immediately understood in Rome. This is evidenced by a report written in November 1828 by Archbishop Caprano of the Congregation for the Propagation of the Faith on the possible consequences of the tsarist ukase. MUH, vol. 8, 133-146. Among the rituals at risk, Caprano also mentions a new practice for the communion of infants. Ibid., 139.

${ }_{54}$ Cf. statement by A. Campodonico, who was in St. Petersburg at the time. MUH, vol. 8 $131 f f$.

55 The main documents on this subject were collected by J. Siemaszko himself, in: op. cit.

56 Ibid., vol. 1, 662ff.

57 Ibid., vol. 2, 14.19

58 Memorial of June 1835, Ibid., vol. 1, 691. 
It was striking that there was no effort on the part of the reformers to convince them of the rightness of the changes introduced. The changes were introduced on a flat-rate basis, under the slogan of de-Latinisation and de-Polonisation. There was not even a list of Latinisms that should be cleaned from the Uniate liturgy - it was to be undertaken automatically, by the very use of the Moscow liturgical book ${ }^{59}$. In addition to the insistence that the clergy should actually celebrate according to these books, the main attention was paid to the introduction of the tsarist gates, the ejection of organs, bells.

The tomb of God decorated in the Polish way or paintings of St. Francis ${ }^{60}$. The "Uniate Work" was completed on 12 February 1839, when the incorporation of the Uniate Church in Russia to the Orthodox Church was officially announced.

Similarly, although with some modifications, the union was liquidated in the Congress Kingdom as part of Russification after Poland's January Uprising $^{61}$. Since it was no longer possible to carry out "nieczuwstwitielno" in this liquidation, its promoters (Bishop-intruder M. Popiel and several dozen priests - apostates from Galicia) were Orthodox from the very beginning. A police method of summoning priests individually was also undertaken in order to force them to adopt the Orthodox Church. There were attempts to convince, but above all the argument that Orthodoxy is the indigenous religion of these lands was developed. In the face of the actual failure of the whole action, an opinion was even voiced that for the liturgy to be purely Orthodox, it is not necessary to fully comply with the Moscow liturgical books ${ }^{62}$.

However, with regard to the communion of infants, the Uniate discipline, as too openly Latin, could not be tolerated. Thus, for example, in the report of an archival visit in 1880 in the former Uniate Orthodox churches of Chełm region, there is information that in some churches, according to the old Orthodox custom, during the bishop's liturgy, children were brought to Holy Communion

59 The only such list can be found in the unfinished work of Siemaszko of $1827 \mathrm{r}$. Soczinienie o Prawoslawii Wostocznoj Cerkwi, printed ibid., vol. 1308 -339. The author mentions, among other things, the abandonment of the communion of infants (p. 332).

60 These cases are, for example, the only subject of a visit to parishes carried out by Siemaszko in 1837. 2, 39-55. Sensitised to the way priests celebrate the liturgy, Siemaszko does not mention giving communion or not to infants. This is probably due to the fact that communion was rarely celebrated at that time.

${ }^{61}$ Cf. J. Pruszkowski, Martyrologium czyli Męczeństwo Unii S-tej na Podlasiu, vol. 1-2, Lublin 1921-1922.

62 Cf. Niedoumjennyje woprosy cerkownej praktiki w sowierszenii bogoslużeniija, Chołmsko-Warszawskij Eparchialnyj Wiestnik 8 (1886), 61f. 
in significant numbers - up to 40 , and up to as many as $60^{63}$. This indicates the introduction of this rite by new hosts and from this point of view it is a secondary matter whether the information concerns a fact or just a desire for a fact. A separate question on this subject in the Catechism's elaboration of the sacrament of Penance and the Eucharist has a similar meaning ${ }^{64}$.

There are still some anti-Latin tendencies to be discussed in the Uniate Church itself. Such tendencies were never lacking in the Uniate Church and they had their prominent representatives also among the hierarchy, e.g. Bishop of Chełm J. Susza (1652-1685) or Archbishop of Polotsk H. Lisowski (1784-1809). The latter began work on the de-Latinisation of the Uniate liturgy, criticising the Zamość synod for this. He justified his intention with a practical objective, i.e. with regard to the enlargement of the Union. Excessive separateness of the Uniate liturgy from the schismatic liturgy, as it is called, alienated the anti-Uniates to the Union, hence the differences had to be reduced to a minimum. The list of Latinisms drawn up by Lisowski on 28 December 1786 in a letter to the Warsaw nuncio F. Saluzzo is extensive ${ }^{65}$. It is striking that there are no changes aimed at taking care of the special respect due to the Blessed Sacrament. Lisowski is also silent about the abandonment of the communion of infants. At the same time, the openness and courage with which the Polotsk archbishop describes the reform he is carrying out suggests that the reason for this silence is not the fear of being put at risk by the Holy See, but rather his own Catholic consciousness, i.e. the awareness of the dimensions of dogmatic changes not included in the list. If this silence was due to tactical reasons, it was at least testimony that the author knew that in the eyes of the Holy See these changes had a connection with dogma.

In the $19^{\text {th }}$ century only the Uniate Church in Galicia could develop normally, but the situation of the union in the Tsardom of Russia contributed to a significant inhibition of anti-Latin tendencies in it. They appeared only marginally and in the form of pro-Orthodox and Belarusian currents ${ }^{66}$. The situation at the time is reflected in the commentary by the Lviv metropolitan $\mathrm{H}$. Jachimowicz to the encyclical Amantissimus of Pius IX dedicated to the

63 Ibid., 2 (1880), 325.

${ }^{64}$ Katichiziczeskoje uczenije prawosławnej Cerkwi o tainstwach Pokajanija i św. Priczaszczenija, Ibid., 6 (1884), 303.

65 This letter was published by M. M. Soloviy, op. cit., 120-125.

66 Galician Ukrainian activists have often complained that Poles exaggerate the importance of these trends. Cf. Annales Ecclesiae Ruthenae (publ. M. Harasiewicz), Leopoli 1862, 1023; H. Jachimowicz, De ritibus observandis, Leopoli 1862, 16. 
Eastern liturgies. The Metropolitan omitted the papal warning against arbitrary reforms in liturgy and the use of liturgical books not approved by the Holy See, believing that it did not apply to his Church ${ }^{67}$. At that time, the decisions of the Zamość Synod were universally adhered to in the matter of communion for children, as can be seen from the reactions of the Galician Uniates to the Eucharistic revival in Pius X's time. They prove that the Latin custom was rooted and unchallenged there ${ }^{68}$.

The internal tension between the two tendencies only revived in the Galician Church after the First World War. The centripetal tendencies were mainly represented in the Lviv environment, under the patronage - albeit with some distance - of Metropolitan A. Szeptycki himself ${ }^{69}$. The main motor behind this trend was the monthly magazine Nywa, headed for many years by H. Kostelnyk, known especially from his activity in 1945. The Ideal Bible of Nywa and the whole current was the famous work of C. Koralewski (real name: Charron) about the Uniate movement ${ }^{70}$. In fact, it was only after its appearance that Byzantinism (as the movement described itself) became apparent as a phenomenon that was important and had a clearly defined ideology ${ }^{71}$. The aim of Byzantinism was to restore its original purity to the Eastern rite. The cossing of different elements in the union was, as it was claimed, the most serious obstacle to its propagation. Kostelnyk even went so far as to dubiously claim that Russia hated the union mainly because it saw it as a tool for the Latinisation and Polonisation of the Russian nation. If the Uniate Church had not been Latinised and Polonised at the time, the Tsardom of Russia, according to the author, would have had almost no reason to persecute the Union ${ }^{72}$. With regard to the Eucharistic customs, Kostelnyk decisively questioned the need for the Eastern rite to accept

67 H. Jachimowicz, op. cit., 12-17.

68 Cf. I. Czarnodola, Ważnist perszoj św. spowidi i perszoho św. pryczastyja ta sposib prigotowanja ditej do sych św. Tajn, Nywa 3 (1906), 285-290.314-320; K. Czechowicz, Dekret św. Apost. Prestola o perszom pryczastyju ditej, Wistnyk Peremyskoj Eparchii 24 (1912), 142-144. The second item is a pastoral letter on the occasion of the decree Quam singulari. K. Czechowicz comments with particular fondness on the passus of the decree, expressing sympathetically about the custom of giving communion to infants in the Eastern liturgies. In his statement, however, there is not even a trace of a postulate to restore this custom in the Galician liturgy.

69 A. Szeptyckyj, Pastyrskyj lyst pro obrjadowi sprawy, Lwiw 1931. The author proclaims the need for moderate de-Latinisation of the Greek liturgy, emphasising that the reform can only be carried out by canonical means.

70 C. Korolevskij, L'uniatisme (Irènikon 5-6), Prieuré d'Amay 1927.

71 H. Kostelnyk, Unija w ewolucji, Nywa 23 (1928), 1-5.

72 H. Kostelnyk, Na zakinczannja, ibid., 24 (1929), 376. 
the liturgical consequences of the doctrine of concomitance ${ }^{73}$. Of course, from this perspective, Eucharistic adoration or resistance to communion for infants is pure Latinism, which stems from Western theology and has nothing to do with Catholic dogma.

The pro-western trend, weaker in number, found its hot leader in the bishop of Stanisławów region, H. Chomyszyn. In his opinion, the liturgical purism of the Byzantines was a deadly threat to the religious vitality of the Uniate Church. He considered the doctrinal hostility of the Byzantines towards the creative religious influences of the Western Church as a manifestation of the schismatic spirit. Understanding the need for a special rite for converts from the Orthodox Church, he believed that the desire to adapt the liturgy more closely to Catholic spirituality would be born in them organically, as they become more deeply rooted in the Catholic Church ${ }^{74}$.

We should also mention the developing neo-Uniate movement in pre-war Poland, which set itself the goal of restoring union in the former Russian partition $^{75}$. Despite celebration of God's service in the rite adopted in the Russian Orthodox Church, i.e. Byzantine-Slavic, it is difficult to see in this movement a manifestation of Byzantine tendencies. Anyway, the movement gathered activists and apostles rather than theorists and theologians. Catholic priests celebrating in this rite gave communion to infants in accordance with its principles ${ }^{76}$.

\section{Summary}

1. The Greek-Latin dispute over the communion of infants is an integral part of the dispute over Eucharistic worship. The reason for the dispute are the changes in the western liturgy as a result of the reaction against Berengar. The changes themselves were based on drawing consequences from the traditional Eucharistic realism, but they are a novelty in relation to specific traditional

73 H. Kostelnyk, Stojannja i kljaczannja w cerkwi, ibid., 24 (1929), 201-209. Kostelnyk studied this problem in depth in printed in parts in subsequent issues of Nywa work on epiclesis from 1928.

74 H. Chomyszyn, Pastyrskyj tyst pro wyzantijstwo, Stanisławiw 1931, 8. Therefore, Chomyszyn defends fervently Eucharistic adoration, devotion to the Sacred Heart, apostolate of prayer. Ibid., 19. $27 \mathrm{n}$.

75 Cf. E. Wyczawski, Ruch neounijny w Polsce w latach 1923-1939, STV 8(1970)1, 409-420.

76 They explicitly provide for communion of infants in the liturgical books of this rite: Liturgical book, Rim 1943, 283-286; Trebnik, vol. 1, Rim 1945, 286-276: and the columns for these books: Treboispolnienije, vol. 2, Rim 1951, $36 f$. 
customs. Thus, Orthodox theology accused the West of illegitimate novelty in relation to traditional rites, while Catholic theology justified the changes with fidelity to the traditional worship of the Blessed Sacrament. Both approaches reflect two different approaches to ecclesiastical tradition. In the East, more attention is paid to the permanence of the deposit received, while in the West, the need for the organic development of tradition is appreciated.

2. In addition, the dispute revealed separate positions on the necessity of the Eucharist for salvation. Some emphasised the sacramentum, while others emphasised res. Eastern theology taught about the necessity of material consumption of the Eucharist, and Simeon of Thessaloniki or Gregory Dattivensis even claimed that anyone who has never consumed the Eucharist can never be saved. Western theology, on the other hand, emphasised that already through baptism man really becomes a member of the Body of Christ.

3. The dispute revealed the different links between the theology of the Eucharist and theology of grace. The Eastern followers of infant communion saw in the Eucharist, above all, the food of a new creation, food for eternal life. Defenders of the Western custom emphasised that infants are free from temptation, so they do not need the help of the Eucharist in the fight against evil. The first theology links the Eucharist rather with the grace of holiness, the second with the grace of works.

4. The diversity of liturgical disciplines is also reflected in pastoral ministry. In the churches that administer all three sacraments of initiation to infants, there is less awareness that anyone, not only a priest, can baptise someone in life-threatening circumstancs.

5. The original attitude towards the other party's otherness was characterised by aggressive reluctance on both sides. However, the allegation of a deviation from the truth appeared only in Eastern theology. This is not some particular merit of Western theology but is due to objective reasons. Western theology, by its very nature, could not sharply stigmatise a custom, the tradition of which was indisputable. 6. At the Florentine Council, which clearly distinguished heresies from legitimate differences, the communion of infants was placed on the list of the latter. However, as the Florentine solutions were not widely accepted, they increased the original diversity of positions. In the Orthodox Church, it is still generally considered dogmatically unacceptable not to grant communion to infants. The position of Orthodox theology has become established especially during anti-Uniate polemics. In the Western Church, on the other hand, the admissibility of the Eastern custom is now clearly proclaimed, however, quite often its own custom is considered to be more appropriate. This teaching was officially confirmed by the Council of Trent. 
7. Uniate theology, in defending the legitimacy of Western custom, basically uses classical Western argumentation, which sees in the Eucharist above all the source of works and graces.

8. In the post-reform period, especially in the polemic after the Brest Union, Catholics of both rites often invoke the communion of infants as a testimony to the legitimacy of communion in one form.

9. The Uniate opponents of the Latinisation of the union most often did not take a clear position on the western influences on the Eucharistic spirituality of the Uniate Churches. The subject of their criticisms were, by their very nature, those manifestations of Latinisation which have no connection with dogma. The silence about transformations in Eucharistic spirituality expressed rather the conviction that these changes were correct. Partly, however, it could have been tactical silence. History also knows of the silence caused by the disregard for theology, which was replaced by official orders and repressions during the liquidation of the union.

10. Using the example of the communion of infants, the difficulty of carrying out a strict borderline between the catholicisation and the Latinisation of the Eastern liturgy is revealed. With regard to Eucharistic customs, this distinction depends on the extent to which the doctrine of concomitance and the liturgical consequences drawn from it in the Western Church belong to the essence of Catholicism, and to what extent they are only a specific feature of Western spirituality. Traditionally, the first alternative was rather accepted, but in the twentieth century there were opinions in favour of a second solution. 